\title{
Application of CISG in Arbitration: A Combined Procedure or Parallel Procedure?
}

\author{
Md. Habib Alam \\ Barrister-at-Law (Lincoln's Inn), United Kingdom \\ Email: drmdhabibalam@gmail.com
}

\begin{abstract}
CISG and arbitration are connected with each other. They may work through a combined or parallel procedure. Globalization of trade desires uniformity in trade. For uniformity of trade, we require uniform law. The arbitration may not work to make it uniform, but choosing any uniform law (i.e. CISG), it may lead to deal a particular arbitration in the international standard. The international standard may be maintained while considering the uniform law. Choosing uniform law (i.e. CISG), it may minimize the risk of wrong interpretation and put the arbitral parties on "equal footing". Parties may consider CISG as the applicable law in their arbitral agreements. As of 13 February 2021, 94 states signed the United Nations Convention on Contracts for the International Sale of Goods 1980 (CISG). ${ }^{1}$ The frontline trading states like the USA, Australia, Israel, Canada, China, Germany, France, Russia, and Japan are contracting states of CISG. This research emphasizes providing guidelines as to how parties may apply CISG into their arbitral agreements by maintaining the international standard.
\end{abstract}

Keywords: CISG, Arbitration, Interpretation, Applicable Law, Uniformity

\section{Introduction}

CISG is known as the United Nations Convention on Contracts for the International Sale of Goods 1980. It is also known as the Vienna Convention 1980. CISG has been signed by 94 states (as of 13 February 2021). The major trading nations are the United States, Canada, China, Germany, France, Russia, Japan, Israel, and Australia. ${ }^{2}$ The main objective of CISG is to get rid of trade barriers in international commerce to uphold international trade around the world. ${ }^{3}$

Arbitration is not a statute or convention like CISG. But technically, it may be both binding and non-binding depending on the circumstances of each case and crystallizing procedure, i.e. turning Arbitration into Mediation and Vice Versa. The main objective of arbitration is to solve national or international dispute resolutions. ${ }^{4}$

\section{Objectives of CISG and Arbitration}

The main objective of CISG is to promote international trade by removing trade obstacles. Article 7(1) of CISG provides "In the interpretation of this Convention, regards is to be had to its international character and to the need to promote uniformity in its application and the observance of good faith in international trade." Both "international character" and "promote uniformity" specify an emphasis on the international standard of interpretation.

\footnotetext{
${ }^{1}$ https://uncitral.un.org/en/texts/salegoods/conventions/sale of goods/cisg/status (accessed on 13 February 2021)

2 https://uncitral.un.org/en/texts/salegoods/conventions/sale_of goods/cisg/status (accessed on 13 February 2021) ${ }_{3}$ https://www.uncitral.org/pdf/english/texts/sales/cisg/V1056997-CISG-e-book.pdf (accessed on 13 February 2021)

${ }^{4}$ Dr. Nils Schmidi-Adrendts, CISG and Arbitration. Website: http://www.cisg.law.pace.edu/cisg/biblio/schmidtahrendts.html (accessed on 13 February 2021)

5https://www.uncitral.org/pdf/english/texts/sales/cisg/V1056997-CISG-e-book.pdf (accessed on 13 February
} 
Legal Scholars suggested, courts and lawyers should spend more time reflecting on different resources to deal with CISG cases. Judges of the competent forums should consider both national and international resources (i.e. different competent forum's decisions of different jurisdictions, writings, and scholar writings, etc.) to interpret the cases in international standard. Judges may also consider different electronic websites (i.e. UNCITRAL, UNILEX, Lexis Nexis, and Westlaw, etc.) for maintaining "International Standard Interpretation Trend" in their judgments or decisions. Under CISG, Judges should avoid considering domestic legal thoughts into CISG disputed matters. ${ }^{6}$

Judges may consider good faith while interpreting cases under Article 7 of CISG. The notion of 'good faith' or bona fide originated from Roman law. There was a rule that, claims should be dealt with according to strict rule. This rule was influenced as a result of a specific standard clause that was inserted by the defendant. The clause was comprised of either good faith or bad faith. This clause gave the judges an equitable discretion to decide the case based on fair and reasonable. ${ }^{7}$

The same "interpretation approach" applies to the interpretation of the international arbitral agreements indirectly. From the international arbitration context, drafting international agreements should maintain an international standard. Standard ICC Arbitration Clauses provide the parties to be free to draft their agreements according to their requirements. It is known as the "tailoring approach" (i.e. freedom of choice of place, language, applicable law). Parties should adopt a "proper drafting approach" while drafting arbitral agreements by avoiding ambiguities and uncertainties. ${ }^{8}$ "Proper drafting approach" will facilitate the competent forum's judges to interpret in international standard including good faith.

\section{A Combined Procedure or Parallel Procedure?}

As we can observe from the above, both arbitration and CISG have a similar trend of an objective by "indirect effect". The combined procedure means as to whether both CISG and arbitration may be combined to get an effective result. On the other hand, as to whether CISG and Arbitration will never meet that means it will run as parallel way, i.e. parallel rail track. This approach is known as the Parallel approach. ${ }^{9}$

From my point of view, Article 6 of the CISG (i.e. parties' discretion/autonomy/freedom) allows the contractual parties of an arbitral agreement to consider the application of CISG with the arbitration (i.e. combined procedure) or not to consider the application of CISG with the arbitration (i.e. parallel procedure).

Article 9(1) of CISG provides "Parties are bound by any usage to which they have agreed and by any practices which they have established between themselves". ${ }^{10}$ The word "any usage...they have agreed" means if parties agree to insert any clause (i.e. based on parties' trade

2021)

${ }^{6}$ Dr. Camilla Baasch Andersen, Francesco G. Mazzotta, Dr. Bruno Zeller, A Practitioner's Guide to the CISG, $1^{\text {st }}$ Edn, Juris, USA, 2010, pg 86-87.

${ }^{7}$ Reinhard Zimmermann, Simon Whittaker, Good Faith in European Contract Law, ${ }^{\text {st }}$ Edn, Cambridge University Press, 2000,pg 16

${ }^{8}$ https://iccwbo.org/publication/standard-icc-arbitration-clauses-english-version/ (accessed on 13 February 2021)

9 Katerina Georgiadou, "Transposing the CISG into the UK legal order: two legislative models". Website: http://www.westlaw.co.uk (accessed on 14 August 2014)

${ }^{10} \mathrm{https}: / / w w w . u n c i t r a l . o r g / p d f / e n g l i s h / t e x t s /$ sales/cisg/V1056997-CISG-e-book.pdf (accessed on 13 February 2021) 
practices) which they have agreed to solve any arbitral dispute through CISG and it will be binding on them unless parties have agreed in other means. In this regard, parties may expressly agree to insert the provisions of CISG (i.e. as a binding clause) into their arbitral agreements. This may be termed as an "express approach". The court may also consider the application of CISG into arbitral agreements based on the circumstances of each case. This may be termed as an "Implied approach."

From the parallel procedure perspective, i.e. where arbitration and CISG will never meet with each other. For example, if another applicable law (i.e. English Sale of Goods $1979^{11}$ or UCC ${ }^{12}$ ) is applied in place of CISG for solving any particular arbitral dispute. However, a competent forum judge may acquire references from the provisions of CISG to deal with any kind of gap or lacuna to solve that particular arbitral dispute. This may be known as a gap-filling procedure, i.e. Article 7(2) of the CISG. ${ }^{13}$

\section{Conclusion}

From the above-mentioned discussion, it may be observed that parties may consider CISG into their arbitral agreements to solve arbitral disputes because of the flexibility of the CISG (i.e. Article 6 of CISG) and to enhance the international standard of interpretation (i.e. Article 7 of CISG). ${ }^{14}$ For choosing CISG in arbitral agreements, the parties do not require to belong to CISG contracting states' list. Parties or competent forums may prefer the CISG into their arbitral agreements expressly or impliedly.

\section{References:}

https://uncitral.un.org/en/texts/salegoods/conventions/sale_of_goods/cisg/status (accessed on 13 February 2021)

https://www.uncitral.org/pdf/english/texts/sales/cisg/V1056997-CISG-e-book.pdf $\quad$ (accessed on 13 February 2021)

Dr. Nils Schmidi-Adrendts, CISG and Arbitration. Website: http://www.cisg.law.pace.edu/cisg/biblio/schmidt-ahrendts.html (accessed on 13 February 2021)

Dr. Camilla Baasch Andersen, Francesco G. Mazzotta, Dr. Bruno Zeller, A Practitioner's Guide to the CISG, $1^{\text {st }}$ Edn, Juris, USA, 2010, pg 86-87.

Reinhard Zimmermann, Simon Whittaker, Good Faith in European Contract Law, $1^{\text {st }}$ Edn, Cambridge University Press, 2000, pg 16

https://iccwbo.org/publication/standard-icc-arbitration-clauses-english-version/ (accessed on 13 February 2021)

Katerina Georgiadou, "Transposing the CISG into the UK legal order: two legislative models". Website: http://www.westlaw.co.uk (accessed on 14 August 2014)

\footnotetext{
${ }^{11}$ http://www.legislation.gov.uk/ukpga/1979/54 (accessed on 13 February 2021)

${ }^{12} \mathrm{https}: / / \mathrm{www}$. law.cornell.edu/ucc (accessed on 13 February 2021)

${ }^{13}$ https://www.cisg.law.pace.edu/cisg/biblio/gap-fill.html (accessed on 13 February 2021)

${ }^{14}$ https://www.uncitral.org/pdf/english/texts/sales/cisg/V1056997-CISG-e-book.pdf (accessed on 13 February 2021)
} 
http://www.legislation.gov.uk/ukpga/1979/54 (accessed on 13 February 2021)

https://www.law.cornell.edu/ucc (accessed on 13 February 2021)

https://www.cisg.law.pace.edu/cisg/biblio/gap-fill.html (accessed on 13 February 2021) 